\title{
ワッシャーを用いた異種材のリベット締結*
}

\author{
木之下 広幸*1, 海 津 浩一*2 \\ 河 村 隆 介*1, 池 田 清 彦*1
}

\section{Riveting Process with Washer for Dissimilar Sheet Metals}

\author{
Hiroyuki KINOSHITA*3, Koichi KAIZU, \\ Ryusuke KAWAMURA and Kiyohiko IKEDA \\ ${ }^{* 3}$ Mechanical Systems Engineering, University of Miyazaki, \\ 1-1 Gakuenkibanadai-nishi, Miyazaki-shi, Miyazaki, 889-2192 Japan
}

\begin{abstract}
In this study, to obtain the high joint strength in riveting of dissimilar sheet metals, the riveting process with a washer was applied to joining. First, both the rivet joints between aluminum and steel with a washer and without it were produced. Next, tensile tests of the joints were carried out and fracture aspects of the joints were investigated in detail, and their joint strength was examined. From the obtained results, it was clarified that fracture aspects of the joints were influenced by the existence of a washer and the joint strength with a washer is higher. It is also confirmed that the riveting process with the washer was effective for joining of dissimilar sheet metals.
\end{abstract}

Key Words : Machine Element, Fixing Element, Riveting, Joint Strength, Washer, Dissimilar Sheet Metal

\section{1. 緒言}

著者らはこれまでに，リベット締結において板の変 形を抑制しつつ高い締結強度を得ることを目的に，水 じ締結と同様にワッシャーを用いてリベット締結する 方法を提案し，アルミニウム合金板同士の締結に同手 法を適用した ${ }^{(1)}$ 。その結果から，単せん断重视継手に おいて，板材よりも変形抵抗の高いリベット材が用い られる場合に, ワッシャーにより締結部の変形が小さ く抑えられるとともに締結強度が増加することを明ら かにした。

異種材をリベット締結する場合には，強度の低い方 の板の締結部周辺の変形が大きくなり, 継手の破壊も 強度の低い方の板の穴周囲で生じやすい，そのような ことから，異種材のリベット継手の特性は強度の低い 板材の機械的性質に影響されてしまうが，可能な限り 締結強度を高めたいという要求法非常に多い。

本研究では，異種材のリベット継手に対してワッシ ヤーを用いたリベット締結法を適用寸ることにより継 手の変形を抑えつつ締結強度の向上が可能かどうかを 検討した．それらの結果について報告する.

* 原稿受付 2010 年 2 月 5 日.

*1 正員, 婷崎大学工学部 (丞 889-2192 宮崎市学園木花台西 11).

*2 正員, 兵庫県立大学大学院 (焉 671-2280 恇路访書写 2167).

E-mail : t0d165u@cc.miyazaki-u.ac.jp

\section{2. 実験方法}

2-1 リベット継手の作製方法＼cjkstart図 1 はワッシャ 一を用いて作製したリベット継手の寸法・形状を示し ている. 本研究では, 板材の変形量と強度が顕著に異 なる異種材のリベット継手におけるるワッシャーの効果 を確かめるために，厚さ $3 \mathrm{~mm} の 一$ 般構造用圧延鋼材 SS400 (降伏応力 : 約 280MPa) の带板と厚さ $1 \mathrm{~mm} の ア$ ルミニウム合金 $\mathrm{A} 1050 \mathrm{P}-\mathrm{H} 24$ 材 (0.2\%耐力 : 約 70MPa) の帯板を締結し，単せん断重る継手を作製した.リベ ット材にはアルミニウム合金A1070Bd 材 (0.2\%耐力： 約 70MPa）を用い，リベットの呼び径（軸直径）は構 造用継手のリベット軸直径と板厚の関係式 ${ }^{(2)}$ から $8 \mathrm{~mm}$ とした. ワッシャーには, 市販の呼び径 $8 \mathrm{~mm}$ のステン レス鋼製のみがき丸（面取り形）を用いた. ワッシャ 一の硬さは $185 \mathrm{HV}$ ，寸法は厚さ1.6m, 外径 $17 \mathrm{~mm}$ ，穴 直径 $8.4 \mathrm{~mm}$ である．板穴の直径は $8.5 \mathrm{~mm}$ とし，板には ドリルで穴あけを施した，リベットは予め，フラット パンチを用いて直径 $8 \mathrm{~mm}$, 長さ $29 \mathrm{~mm}$ の棒材から据込み 加工により作製した.なお，リベット頭部の直径 $D$ は, リベット軸の直径 $d_{0}(8 \mathrm{~mm})$ の約 1.7 倍に成形した. 継 手は図 1 に示寸ように, 強度が低く変形量の大きい A1050P-H24 の板材の上面のみにワッシャーを設けた 継手と，ワッシャ一無しの継手を作製した。リベット 締結は図 2 に示すように, SS400 の带板の上に 
A1050P-H24 の帯板を重ね，ワッシャーを用いる場合に はその上にワッシャーを置いて，下側から穴にリベッ ト軸を挿入した後に，リベット軸をフラットパンチに より圧縮することにより行った．なお，本研究で用い たリベット材 (A1070Bd) と板材 (A1050P-H24) の 0.2\% 耐力はほぼ同じであるが，リベット軸はかしめ加工に より穴内に押し広げられ，塑性ひずみを生じて加工硬 化する.そのため, 締結後のリベット軸の変形抵抗は, 板材よりも大きくなる.

2.2 継手の強度試験の方法 図 3 は, 継手の強 度試験の方法を示している. 強度試験はオ一トグラフ （島津製 $\mathrm{AG}-\mathrm{X} 50 \mathrm{kN}$ ）を用いて，上下のチャックの余裕 を利用して 2 枚の板が負荷方向に平行になるように継 手の両端をつかみ, $10 \mathrm{~mm} / \mathrm{min}$ の一定速度で引張ること により行った.

\section{3. 実験結果および考察}

3.1 締結部の梾相 図 4 は, ワッシャ一無しの 継手とワッシャ一有りの継手の締結部断面の様相を示 している. ワッシャ一無しの継手は，アルミニウム合 金板の穴縁がリベットの軸と頭部により圧縮されて塑 性変形し, 穴に近いほど板厚が減少している。一方, ワッシャー有りの継手にはこのような現象は生じてい ない．これらの締結部断面の状況から，ワッシャ一無 しの継手の場合では, 板の穴縁に近い部分はリベット 頭部により強く締めつけられているが，リベット頭部 の外周部付近ではあまり締めつけられていないと推測 される. それに対して，ワッシャー有りの継手の場合 では，板はワッシャーにより広い領域で一様に締めつ けられていると推測される.

\section{2 締結部の破溒の様相 図 5 は, 継手の引張} 試験後の破壞の様相と引張試験時の荷重一変位曲線の 一例を示している. 図 5(a)に示すワッシャ一無しの継 手の場合には，アルミニウム合金の板穴周囲がリベッ トの圧縮力に耐えか孙て拡大寸るとともに，板の端部 が大きく開く特徵がある.これらの様相からこの場合 の破壊の形態は，板穴周囲が圧縮破壊される形態 (2),

(3) と考えられる. 一方, 図 5(b)に示すワッシャ一有 りの継手の場合は，アルミニウム合金の板穴は継手の 長手方向にのみ搪大し，リベット軸によって圧縮され た板の穴周辺が板の端部まで押出されている現象が観 察される. そして，その板の端部に押出された部分に は寸べり線が観察される。.また，この場合は板の端部 には開きは生じていない.さらに図5(c)に示すように, ワッシャ一無しの継手の場合には，小さなストローク で最大荷重に達し，継手はすぐに破壊してしまうが，

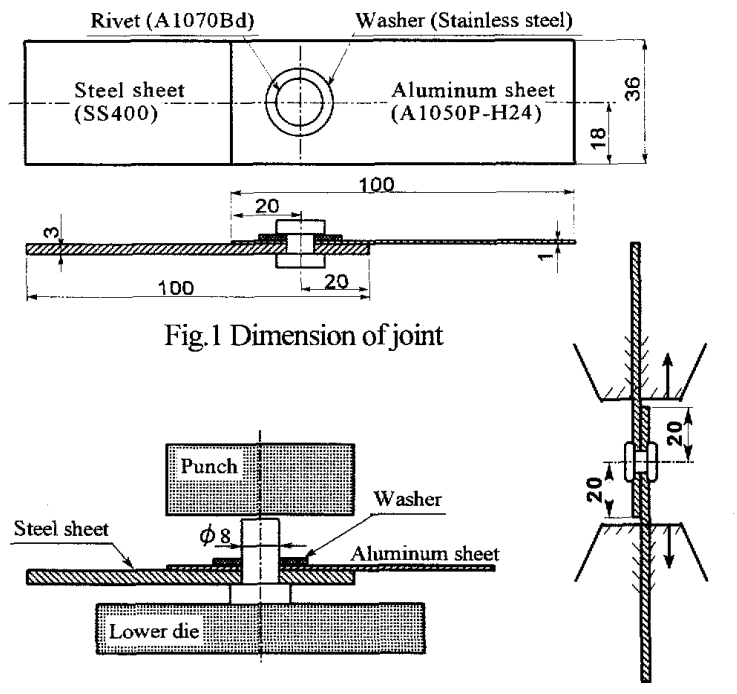

Fig.2 Method of joining

Fig.3 Tension test of joint

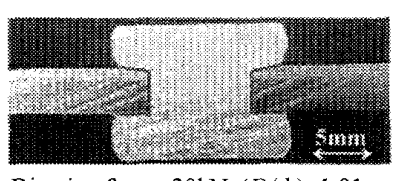

Riveting force $=30 \mathrm{kN},\left(D / d_{0}\right)=1.81$ (a) Without washer

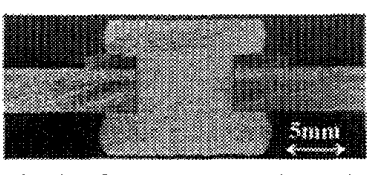

Riveting force $=30 \mathrm{kN},\left(D / d_{0}\right)=1.79$ (b) With washer
Fig.4 Section of joints
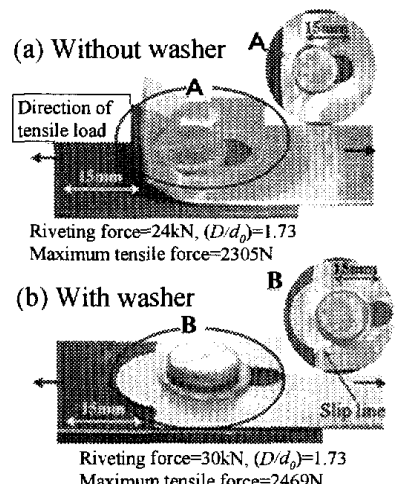
Maximum tensile force $=2469 \mathrm{~N}$

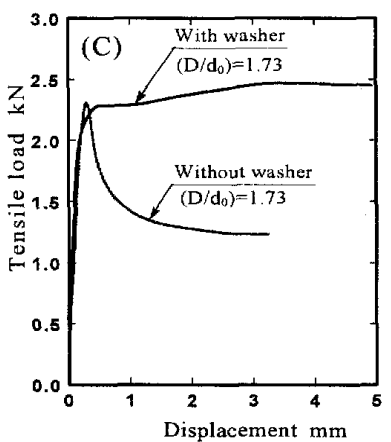

Fig.5 Fracture aspects and tensile load-displacement curves

ワッシャー有りの継手の場合には，破壇に至るまでの ストロークが非常に長く，しばらくの間，ほぼ一定の 荷重で推移する特徵がある。これらの様相からこの場 合の破壊の形態は，板穴周囲が圧縮破壊される形態と リベットと板の端部の間の部分がせん断されて破壊す る形態 ${ }^{(2),(3)}$ の複合型と考えられる. 但し, リベット 頭部の直径 $D$ とリベット軸の直径 $d_{0}$ の比 $\left(D / d_{d}\right)$ が約 1. 85 以上になると板穴周囲は圧縮破壊され，破壊形態 に差異はなくなる，以上から，ワッシャーには継手が 引張力を受けた際に，板穴の桩大ならびに板と板との 間の開きを抑制する両方の作用があると考えられる。 なお，継手が引張力を受けた際に板と板との間に開き が生じる原因は, 継手の雨端の引張力にともないりべ ットおよび板に曲げモーメントが作用するためである 
(1)。またワッシャーが板と板との間の開きを抑制す る理由は，これまでの有限要素法による継手の引張試 験の解析結果 (1) から，ワッシャーと板との接触部付 近一带に圧縮応力が作用するためと考えられ，板の開 きが抑制されると板と板との間の摩擦力の減少を防ぐ 効果をもたらす。

3.3 継手の強度 図6は,継手の最大引張荷重を 表している. 図中の○およびロの印が引張試験で得ら れた最大引張荷重を表し，一点鎖線は，板穴周囲がリ ベット軸により圧縮破壊される場合の圧縮力 $F_{A}$ (支圧 力: Bearing）を次式 (3) により計算した結果を表して いる.

$$
F_{A}=\sigma \cdot d \cdot t
$$

ここで， $\sigma$ はアルミニウム合金板の圧縮の変形抵抗， $d$ 締結後のリベット軸の直径 $(8.5 \mathrm{~mm}), t$ はアルミニ ウム合金の板厚 $(1 \mathrm{~mm})$ を表す。また実線は，リベットと アルミニウム合金板の端部の間の部分がせん断されて 破壊する場合のせん断力 $F_{B}$ (Shearing) を次式 (3)によ り計算した結果を表している.

$$
F_{B}=2 \cdot e \cdot t \cdot \tau
$$

ここで，てはアルミニウム合金板のせん断変形抵抗， $e$ はリベット穴の中心から板の端までの長さ $(20 \mathrm{~mm})$ を 表す。計算では， $\sigma$ には A $1050 \mathrm{P}-\mathrm{H} 24$ 材の $0.2 \%$ 耐力 $(70 \mathrm{MPa})$ を用い， $\tau$ にはミーゼスの降伏条件から $\sigma$ の值を $\sqrt{3}$ で除した值 $(40.4 \mathrm{MPa})$ を用いた。図6から， ワッシャ一無しの継手とワッシャー有りの継手の最大 引張荷重は， $(D / d) か ゙ ~ 1.8$ 以上ではあまり変わらない が，(D/ddが 1.6 から 1.8 末満の範井では明らかにり ッシャ一有りの継手の方が大きい,このように，(D/d) が小さい場合に継手の最大引張荷重の差が大きいのは, ワッシャ一無しの継手の場合には，(D/d)の増加とと もに最大引張荷重が増加する特徴があるが，これに対 してワッシャ一有りの継手の場合には, 最大引張荷重 は $\left(D / d_{0}\right)$ の大きさによらずほぼ一定でかつ大きいこと による。ワッシャ一無しの継手の最大引張荷重が $\left(D / d_{0}\right)$ の増加とともに増加する理由は, 図 5 の締結部 断面の椂相から，リベット頭部の直径が大きいほど大 きな面積で板を締め付けているためと考えられる。ま た，ワッシャー有りの継手の最大引張荷重が，(D/d) の大きさによらずほぼ一定となる理由は，リベット頭 部の直径によらず，ワッシャ一の座面で板を締め付け ているためと考えられる.

次に，ワッシャー有りの継手の最大弓張荷重が相対 的に大きい理由について以下のように考察する。 $3 \cdot 2$ 節で述べたように，ワッシャー無しの継手は板穴周囲

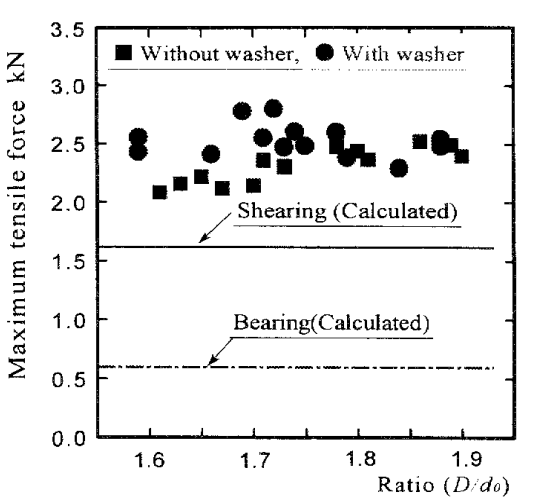

Fig.6 Maximum tensile force of joints

の圧縮破壊であり，ワッシャ一有りの継手の場合は， 板穴周囲の圧縮破壊とリベットと板の端部の間の部分 のせん断破壊の複合型と考えられる。また，図6中の 実線上一点鎖線の比較力ら，せん断力は支圧力よりも 2 倍以上も大きく，部分的にでも板のせん断破壞をと もなうワッシャ一有りの継手は高い強度を持つものと 考えられる，なお，図6に拈いて，破壊の形態が異な るのにワッシャー無しの継手とワッシャ一有りの継手 の最大引張荷重があまり変わらない原因の一つは，締 結後のリベット頭部の締め付け力によって生じる板と 板との間の摩擦力が継手の強度に大きく影響を及ぼし ているためと考えている．したがって，単純に式(1) と式(2)のみから継手の強度を推定することはでさな いが，式(1)および式(2) は継手の強度を検討する上で の重要な要因であると考えられる.

ワッシャーを用いた場合の特徵は，図6に示したよ うにリベット頭部が小さい場合にも比較的高い締結強 度が得られることで女る。この特性は，リベット締め 荷重を小さくして板の変形を小さく抑えたい場合に有 用であると考えられる。

\section{4. 結言}

本研究では, SS400 の帯板と A1050P-H24 の帯板に対 してワッシャーを用いたリベット締結法を適用し，異 種材継手の変形の抑制と締結強度の向上に対するワッ シャ一の効果について検討した. その結果, ワッシャ 一を用いることで継手の破壊の様相に明確な違いが見 られ継手の強度も向上することを明らかにした。

\section{文献}

(1)Kinoshita, H., et al., Proposal and effect of riveting process using the washer, Transactions of the Japan Society of Mechanical Engineers, Series C, Vol.74, No.745 (2008), pp.2281-2288.

(2) Masuko, M., Machine Design, (1985), pp.71-92, Yokendo Co. Ltd.

(3) Oonishi, K., Hand book of Design and Drawing based on JIS, (1987), p.(13-11), Rikogakusha Publishing Co. Ltd. 